\title{
Non-Hodgkin Lymphoma and Pleural Mesothelioma in a Person Exposed to Asbestos
}

\author{
Claudio BIANCHI, Tommaso BIANCHI \\ Italian League Against Cancer, Center for the Study of Environmental Cancer, MONFALCONE, ITALY
}

\begin{abstract}
Non-Hodgkin lymphoma and pleural mesothelioma may co-exist in the same patient. A large cell non-Hodgkin lymphoma of the inguinal lymph nodes was diagnosed in a 73-year-old woman. The patient was treated by chemotherapy. She did not receive radiotherapy. The patient had been exposed to asbestos having worked in a cotton mill and in a distillery. Four years after the diagnosis of lymphoma, she presented with a left pleural effusion. Large biopsies of the pleura showed a malignant mesothelioma, biphasic type, and pleural plaques. Epidemiological studies about the asbestos-lymphoma relationship gave conflicting results. The lymphoma-mesothelioma association is not exceptional, and suggests that asbestos plays a role in the etiology of both malignancies.
\end{abstract}

Key Words: Non-Hodgkin Lymphoma, Mesothelioma, Asbestos

\section{INTRODUCTION}

Many cases in which non-Hodgkin lymphoma and pleural mesothelioma co-existed in the same patient have been reported (1-3). Such occurrence raises the question of whether common etiological factors might play a role in the genesis of the two malignancies. We report a further case of such an association.

\section{CASE REPORT}

In 1997 a 73-year-old woman presented with a swelling of the inguinal lymph nodes. A biopsy showed a large cell non-Hodgkin lymphoma. The patient had a history of occupational exposure to asbestos. She had worked for some years (1939-1943) in a cotton mill in Gorizia. Subsequently, she had been employed at a distillery in Gorizia for about 25 years (1955-1980). Her jobs in this factory included the preparation of asbestos powder for filtering the spirits. The patient was treated by chemotherapy for six months. She did not receive radiotherapy.

In November 2001 the patient was admitted at the General Hospital of Gorizia for dyspnea and weight loss. A radiography of the thorax showed a left pleural effusion. The clinical suspicion was lymphoma recurrence. However, at the cytological examination of the pleural fluid, clusters of epithelial atypical cells aggregated in papillary structures were visible. In December 2001, a left videothoracoscopy showed several nodules and pleural plaques. Multiple biopsies were performed. Histological

(Turk Patoloji Derg 2018, 34:190-193)

Received : 06.05.2015 Accepted : 14.08.2015 examination documented a malignant mesothelioma, biphasic type (Figures 1-4). In the following months, the general conditions of the patient showed progressive deterioration and she died in December 2002, one year after the mesothelioma diagnosis.

\section{DISCUSSION}

In the current case, the patient had been exposed to asbestos in two different workplaces. In the first period (1939-1943), she had worked in a cotton mill in Gorizia. Such factory has already been identified as the source of asbestos exposure in several mesothelioma cases (4). In the second period (1955-1980) the patient had worked in a distillery, where she prepared asbestos powder for filtering the spirits. Besides the occupational history, asbestos exposure was documented by the presence of pleural plaques detected at the videothoracoscopy. Undoubtedly, pleural mesothelioma in the present case has to be considered as the effect of asbestos.

Therelationship between asbestos exposureand tumors of the hematopoietic system has been the subject of investigations for some 50 years. In 1966 Lieben (5), by examining 68 cases of pulmonary asbestosis, found 21 malignancies; these included two cases of lymphocytic leukemia, one case of acute leukemia, one case of lymphoblastoma, and one case of multiple myeloma. In 1970 Gerber (6), by studying 35 cases of asbestosis at necropsy, observed two cases of multiple myeloma, two cases of myeloproliferative

Correspondence: Claudio BIANCHI

Italian League Against Cancer, Center for the Study of Environmental Cancer, Hospital of Monfalcone, MONFALCONE, ITALY

E-mail: legatumori1@interfree.it Phone: +39048144007 


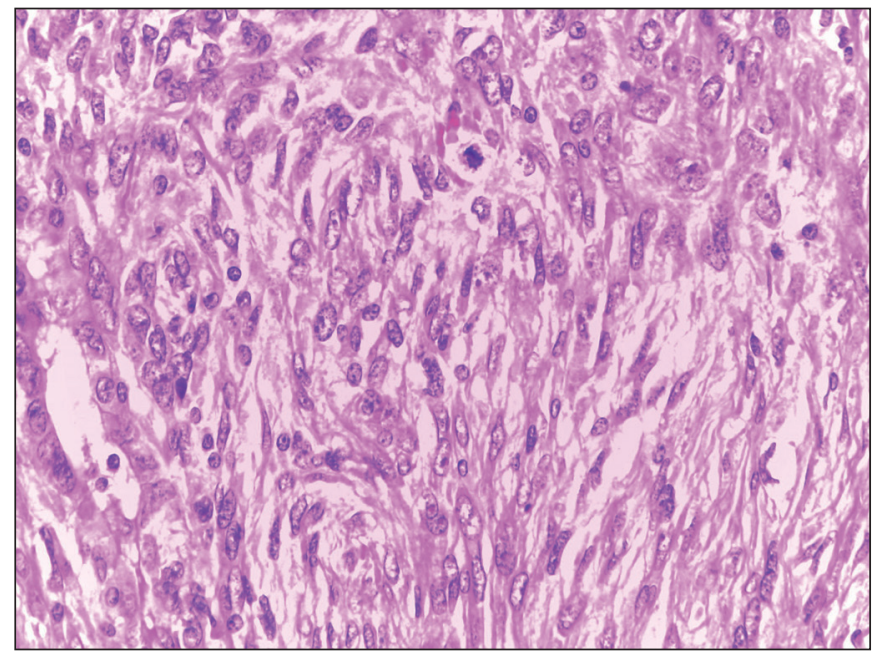

Figure 1: Pleural biopsy. Neoplastic cells with ovoidal or elongated nuclei are arranged in bundles. At the left margin a pseudotubule is visible, composed by cuboidal epitheliomorphic cells (H\&E; $\mathrm{x} 200)$.

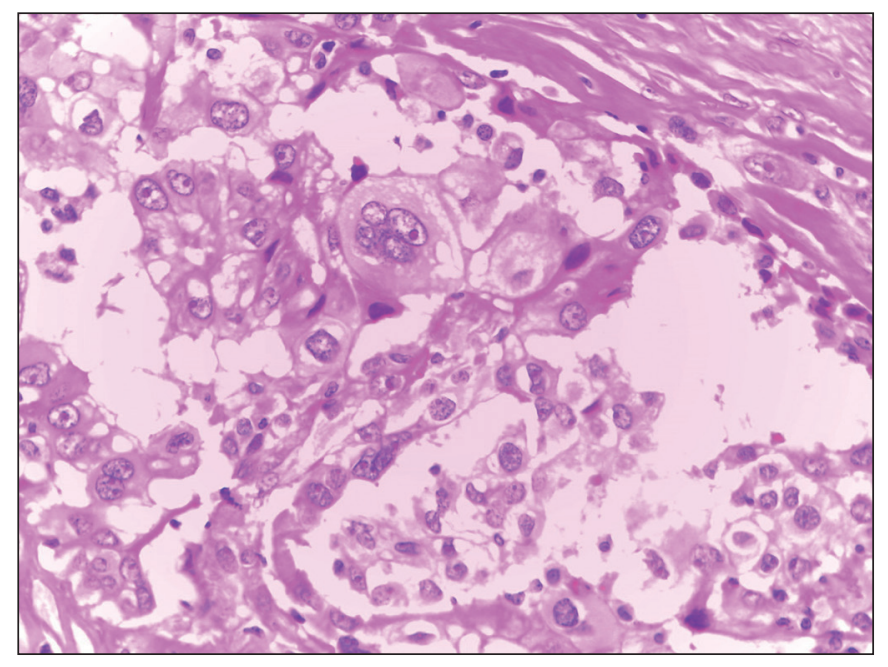

Figure 3: Spheroid and polyhedral atypical cells are collected in clusters or are bordering irregular lacunae. The cytoplasm is often vacuolated, the nucleoli are frequently prominent. One giant multinucleated cell is also visible (H\&E; x 400).

disorders and one case of Waldeström macroglobulinemia. The researcher concluded that the hematopoietic tumors were significantly more frequent in subjects with asbestosis than those without. In 1982 Ross et al. (7) found an excess of lymphomas of the gastrointestinal tract and oral cavity among subjects exposed to asbestos in a case-control study. Moreover, numerous cases have been reported in which an asbestos-related mesothelioma or other asbestos-related conditions were associated with lymphomas or other lymphoproliferative lesions (1-3, 8-15). In 2001 Becker et al. (16) concluded in a review of the literature on this

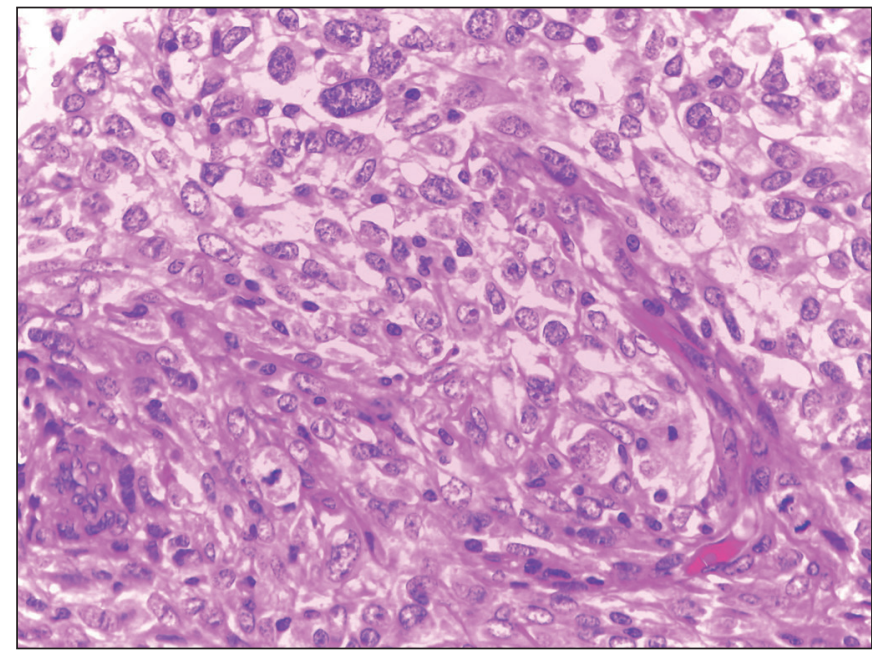

Figure 2: Sheet of epithelial-like, atypical cells. The nuclei are oval or irregular with prominent nucleoli (H\&E; x400).

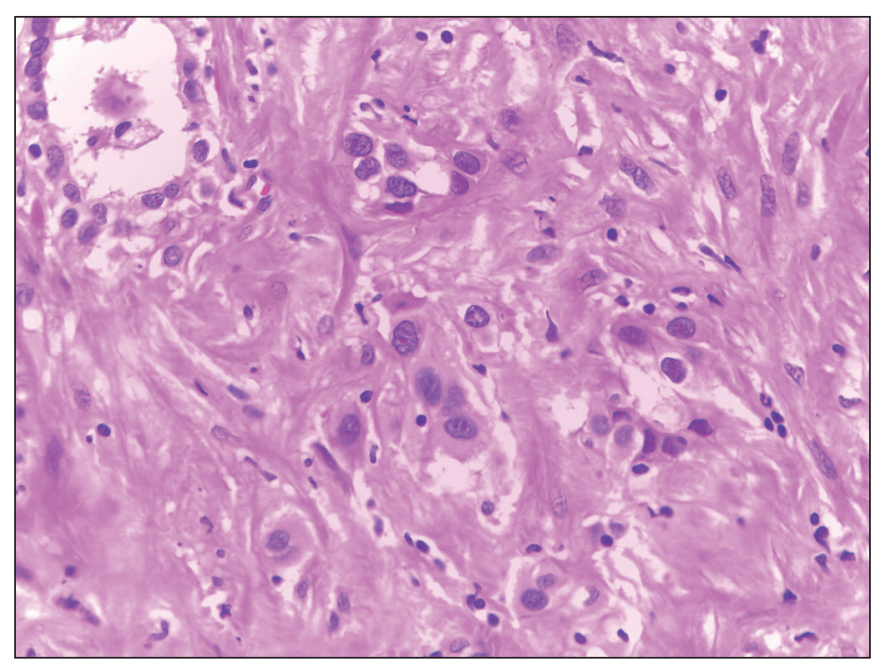

Figure 4: Epitheliomorphic polyhedral cells are scattered in a fibrohyaline stroma or are bordering a pseudotubule (H\&E; $\mathrm{x}$ 400).

issue that taken as a whole, the available data indicated an increase of lymphoma risk after exposure to asbestos. More recent studies provided conflicting results (17-19).

It is in some way surprising that some accepted conclusions about the relationship between asbestos and non-Hodgkin lymphoma did not emerge in a field so largely and deeply explored in the 20th century such as asbestos and cancer. There are various possible explanations for these discrepancies. Firstly, the non-Hodgkin lymphoma label covers a variety of neoplasms. One may suppose that some agents or conditions represent risk factors for some types of lymphoma, and not for others (20). This fact may hide some etiologically relevant agents when non-Hodgkin 
lymphomas are considered as a whole. In addition, the causes of non-Hodgkin lymphomas are various (and largely not known). The global epidemiology of lymphoma shows very marked variations in the incidence of these neoplasms from one part of the world to the other (21). This suggests that the causes (genetic and environmental) as well as the cofactors relevant in the etiology of non-Hodgkin lymphomas might differ substantially in the various geographical areas. If this is true, one cannot expect homogeneous results in the different geographical areas.

The development of non-Hodgkin lymphoma and asbestosrelated mesothelioma in the same patient has repeatedly been observed. In particular, mesothelioma was associated with a non-Hodgkin lymphoma in three cases in a series of 169 pleural mesotheliomas examined at necropsy at the Monfalcone Hospital; in two of the cases the lymphoma was extranodal, being located in the brain and in the liver (1).

Numerous cases in which malignant mesothelioma and lymphoproliferative lesions were associated have recently been reported. Li et al. have examined a large series of mesotheliomas including more than 3,600 cases (3). The authors observed 45 cases with mesothelioma and hematologic malignancy. These included Hodgkin lymphoma (18 cases), non-Hodgkin lymphoma (15 cases), chronic lymphocytic leukemia (10 cases), and chronic myelogenous leukemia ( 2 cases). Nineteen patients (16 with Hodgkin lymphoma and 3 with non-Hodgkin lymphoma) had a history of radiotherapy. The role of radiation in the etiology of mesothelioma is demonstrated. In addition, various data suggest a synergism between radiation and asbestos. This means that radiation only or the radiation-asbestos couple may be responsible for mesothelioma among subjects with previous radiotherapy in the above series. However, a majority of the non-Hodgkin lymphomas were not treated with radiotherapy. It is difficult to attribute the mesothelioma-lymphoma association to fortuitous circumstances. $\mathrm{Li}$ et al. (3) reported that BAP1 (BRCA1 associated protein 1), mutated in many mesotheliomas and has a role in the regulation of hematopoietic stem cell function. Various recent findings regarding the occurrence of familial mesotheliomas indicate that genetic factors play a role in the genesis of asbestos-related mesothelioma (22-25). The association of mesothelioma and non-Hodgkin lymphoma deserves further investigation from this point of view as well. Finally, the fact that asbestos may induce important changes in the immune system (26-28) corroborates the idea that the mineral plays a role in lymphoma etiology. In fact, immune impairment is recognized as a favouring factor in the development of lymphomas (29).

\section{REFERENCES}

1. Bianchi C, Bianchi T, Ramani L. Malignant mesothelioma of the pleura and other malignancies in the same patient. Tumori. 2007;93:19-22.

2. Bianchi C, Bianchi T, Bucconi S. Non-Hodgkin lymphoma of the testis and malignant mesothelioma of the pleura in the same patient. Eur J Oncol. 2010;15:167-71.

3. Li X, Brownlee NA, Sporn TA, Mahar A, Roggli VL. Malignant (diffuse) mesothelioma in patients with hematologic malignancies: A clinicopathologic study of 45 cases. Arch Pathol Lab Med. 2015;139:1129-36.

4. Bianchi C, Bianchi T, Ramani L. Mesotelioma maligno della pleura nella donna. Med Lav. 2004;95:276-80.

5. Lieben J. Malignancies in asbestos workers. Arch Environ Health. 1966;13:619-21.

6. Gerber MA. Asbestosis and neoplastic disorders of the hematopoietic system. Am J Clin Path. 1970;53:204-8.

7. Ross R, Dworsky R, Nichols P, Paganini-Hill A, Wright W, Koss M, Lukes R, Henderson B. Asbestos exposure and lymphomas of the gastrointestinal tract and oral cavity. Lancet. 1982;2:1118-20.

8. Perry MC, Solinger A, Farhangi M, Luger A. Plasmacytomas and mesothelioma. Med Ped Oncol. 1978;5:205-12.

9. Kagan E, Jacobson RJ. Lymphoid and plasma cell malignancies: Asbestos-related disorders of long latency. Am J Clin Pathol. 1983;80:14-20.

10. Longo MS, Giordano D, Papa D, Venzano C. Su di un caso di associazione mesotelioma IgG-mieloma. Rivista Ospedale Sampierdarena. 1983;21:29-38.

11. Bianchi C, Brollo A, Bittesini L. Esposizione all'asbesto e linfomi non-Hodgkin nel territorio di Monfalcone. In: Furbetta D, Abbritti G, editors. $47^{\circ}$ Congresso della Società Italiana di Medicina del Lavoro e Igiene Industriale. Bologna: Monduzzi Editore; 1984;1077-80.

12. Efremidis AP, Waxman JS, Chahinian AP. Association of lymphocytic neoplasia and mesothelioma. Cancer. 1985;55: 1056-9.

13. Hayashi Y, Mizuo K, Hayashi K. An autopsy case of double cancer of multiple myeloma and malignant mesothelioma (in Japanese). Nihon Naika Gakkai Zasshi. 1989;78:1611-2.

14. Oksa P, Pukkala E, Karjalainen A, Ojajärvi A, Huuskonen MS. Cancer incidence and mortality among Finnish asbestos sprayers and in asbestosis and silicosis patients. Am J Ind Med. 1997;31:693-8.

15. Bianchi C, Di Bonito L, Brollo A, Bittesini L. Primary lymphoma of the brain and asbestosis (abstract). Acta Neurologica. 1983;5:308.

16. Becker N, Berger J, Bolm-Audorff U. Asbestos exposure and malignant lymphomas-a review of the epidemiological literature. Int Arch Occup Environ Health. 2001;74:459-69.

17. Weisenburger DD, Chiu BC. Does asbestos exposure cause non-Hodgkin's lymphoma or related hematolymphoid cancer? A review of the epidemiologic literature. Clin Lymphoma. 2002;3:36-40. 
18. Mester B, Nieters A, Deeg E, Elsner G, Becker N, Seidler A. Occupation and malignant lymphoma: A population-based casecontrol study in Germany. Occup Environ Med. 2006;63:17-26.

19. Seidler A, Becker N, Nieters A, Arhelger R, Mester B, Rossnagel K, Deeg E, Elsner G, Melis M, Sesler S, Avataneo G, Meloni M, Cocco P. Asbestos exposure and malignant lymphoma: A multicenter case-control study in Germany and Italy. Int Arch Occup Environ Health. 2010;83:563-70.

20. Pukkala E, Martinsen JI, Lynge E, Gunnarsdottir HK, Sparén P, Tryggvadottir L, Weiderpass E, Kjaerheim K. Occupation and cancer - follow up of 15 million people in five Nordic countries. Acta Oncol. 2009;48:646-790.

21. World Cancer Report. Stewart BW, Kleihues P, editors. Lyon: IARC Press; 2003.

22. Bianchi C, Brollo A, Ramani L, Bianchi T, Giarelli L. Familial mesothelioma of the pleura. A report of 40 cases. Ind Health. 2004;42:235-9.

23. Bianchi C, Bianchi T. Pleural mesothelioma in a couple of brothers. Indian J Occup Environ Med. 2013;17:122-3.

24. de Klerk N, Alfonso H, Olsen N, Reid A, Sleith J, Palmer L, Berry G, Musk AB. Familial aggregation of malignant mesothelioma in former workers and residents of Wittenoom, Western Australia. Int J Cancer. 2013;132:1423-8.
25. Ascoli V, Romeo E, Carnovale Scalzo C, Cozzi I, Ancona L, Cavariani F, Balestri A, Gasperini L, Forastiere F. Familial malignant mesothelioma: A population-based study in Central Italy (1980-2012). Cancer Epidemiol. 2014;38:273-8.

26. Froom P, Lahat N, Kristal-Boneh E, Cohen C, Lerman Y, Ribak J. Circulating natural killer cells in retired asbestos cement workers. J Occup Environ Med. 2000;42:19-24.

27. Otsuki T, Maeda M, Murakami S, Hayashi H, Miura Y, Kusaka M, Nakano T, Fukuoka K, Kishimoto T, Hyodoh F, Ueki A, Nishimura Y. Immunological effects of silica and asbestos. Cell Mol Immunol. 2007;4:261-8.

28. Nishimura Y, Miura Y, Maeda M, Kumagai N, Murakami S, Hayashi H, Fukuoka K, Nakano T, Otsuki T. Impairment in cytotoxicity and expression of NK cell-activating receptors on human NK cells following exposure to asbestos fibers. Int J Immunopathol Pharmacol. 2009;22:579-90.

29. Bianchi C, Bianchi T. Susceptibility and resistance in the genesis of asbestos-related mesothelioma. Indian J Occup Environ Med. 2008;12:57-60. 